\title{
Rippled scour depressions add ecologically significant heterogeneity to soft-bottom habitats on the continental shelf
}

\author{
Todd R. Hallenbeck ${ }^{1}$, Rikk G. Kvitek ${ }^{2, *}$, James Lindholm ${ }^{3}$ \\ ${ }^{1}$ West Coast Governors Alliance, Office of the Governor, Salem, Oregon 97301, USA \\ ${ }^{2}$ Seafloor Mapping Laboratory and ${ }^{3}$ Institute for Applied Marine Ecology, California State University, Monterey Bay Seaside, \\ California 93955, USA
}

\begin{abstract}
Comprehensive mapping of California's state waters has revealed rippled scour depressions (RSDs) to be abundant and widespread on the inner continental shelf. Ranging from $100 \mathrm{~s}$ to $1000 \mathrm{~s}$ of $\mathrm{m}^{2}$ in areal extent, RSDs are 30 to $50 \mathrm{~cm}$ deep depressions of coarser sediments and longer period bedforms than found on the surrounding seabed. Although RSDs have been physically described on many continental margins, previous studies have not addressed the ecological influence and associated biological communities of RSDs. Here, we test the hypothesis that there are ecologically important differences in the distribution and abundance of benthic fish and invertebrate groups inside and outside RSDs. A small ROV was used to survey 20 RSDs in 3 depth zones $(<15 \mathrm{~m}, 15$ to $30 \mathrm{~m}$, and $>30 \mathrm{~m})$ within Monterey Bay, California. Density and richness of benthic communities were determined from the recorded video imagery. Sediment grab samples confirmed significantly larger mean grain sizes inside $(0.71 \mathrm{~mm})$ than outside $(0.22 \mathrm{~mm})$ the RSDs. Overall mean faunal density (fish and invertebrates) was lower inside RSDs in the shallow, intermediate, and deep zones $\left(0.32,1.61\right.$, and 2.17 ind. $10 \mathrm{~m}^{-2}$ respectively) than outside $(0.38,3.06$, and 4.48 ind. $10 \mathrm{~m}^{-2}$ ). Faunal richness was also lower inside RSDs in each depth zone $(0.29,1.03$, and 1.43 taxa $\left.10 \mathrm{~m}^{-2}\right)$ than outside RSDs $\left(0.29,1.72\right.$, and 2.48 taxa $\left.10 \mathrm{~m}^{-2}\right)$. Surprisingly, RSDs did contain significantly more young-of-the-year rockfishes and small flatfishes than adjacent fine sediments, suggesting a possible nursery function for these otherwise depauperate coarsegrained habitats. These results indicate that RSDs can add a significant and previously undescribed level of ecological patchiness to soft sediment communities on the continental shelf.
\end{abstract}

KEY WORDS: Rippled scour depressions $\cdot$ Continental shelf $\cdot$ Marine spatial planning $\cdot$ ROV $\cdot$ Soft sediment $\cdot$ Benthic ecology $\cdot$ Sorted bedforms $\cdot$ Sebastes

\section{INTRODUCTION}

The role of water depth and temperature, as well as substrate type, in the large-scale distribution and abundance of benthic communities has been well described (Warwick \& Davies 1977, Langton \& Watling 1990, Barry \& Dayton 1991, Snelgrove \& Butman 1994, Whitman et al. 2004). Typically, the abundance of fishes and invertebrates increases with water depth in the unconsolidated sediment habitats of the continental shelf (Allen \& Moore 1996, Kostylev et al. 2001). Within sediment habitats, the distribution of benthic organisms is mediated by a variety of factors, including grain size (Butman et al. 1988, Snelgrove 1999, Brown \& Collier 2008), hydrodynamic forces (Aller 1997, Pillay et al. 2007), bedform type (Auster et al. 2003a, Lindholm et al. 2004), and biogenic structure and biotic interaction (Woodin 
1978, Auster et al. 1991, Zajac et al. 1998, Auster et al. 2003b, Diaz et al. 2003, Lindholm et al. 2007, Stoner et al. 2007).

Rippled scour depressions (RSDs; Fig. 1) have been identified and physically described in small-scale studies on many of the world's continental shelves (Garnaud et al. 2005, Gutierrez et al. 2005, Lo Iacono \& Guillen 2008, Bellec et al. 2010). These elongate shallow depressions ( 0.3 to $1 \mathrm{~m}$ in depth), oriented normal to isobathic contours, are characterized by long crested bedforms ( 0.5 to $1 \mathrm{~m}$ wavelength), coarse sediment $(0.3$ to $1 \mathrm{~mm})$, and abundant shell hash. RSDs have been found in water depths of 15 to $160 \mathrm{~m}$ with reported dimensions of 30 to $250 \mathrm{~m}$ wide and 100 to $3000 \mathrm{~m}$ long (Cacchione et al. 1984, Bellec et al. 2010). The sediments surrounding RSDs are typically characterized by finer grain size 0.05 to $0.3 \mathrm{~mm}$ ), shorter period bedforms, and a sharp edge delineating the coarser-grained RSDs (Green et al. 2004, Goff et al. 2005, Diesing et al. 2006). Further, RSDs can be persistent, with their spatial extent and boundaries remaining stable for decades (Diesing et al. 2006).

Although previous studies provide detailed information on the physical characteristics of RSDs at the local scale, regional-scale assessments of RSD distribution and abundance were not possible with the available data. Now, with the completion of the California Seafloor Mapping Project (CSMP), comprehensive high-resolution multibeam sonar maps indicate that RSDs cover nearly as much of the state's $1200 \mathrm{~km}$ long continental shelf as does rocky habitat (5\% and $8 \%$ respectively), with RSDs representing the most prominent and widespread soft-bottom fea-
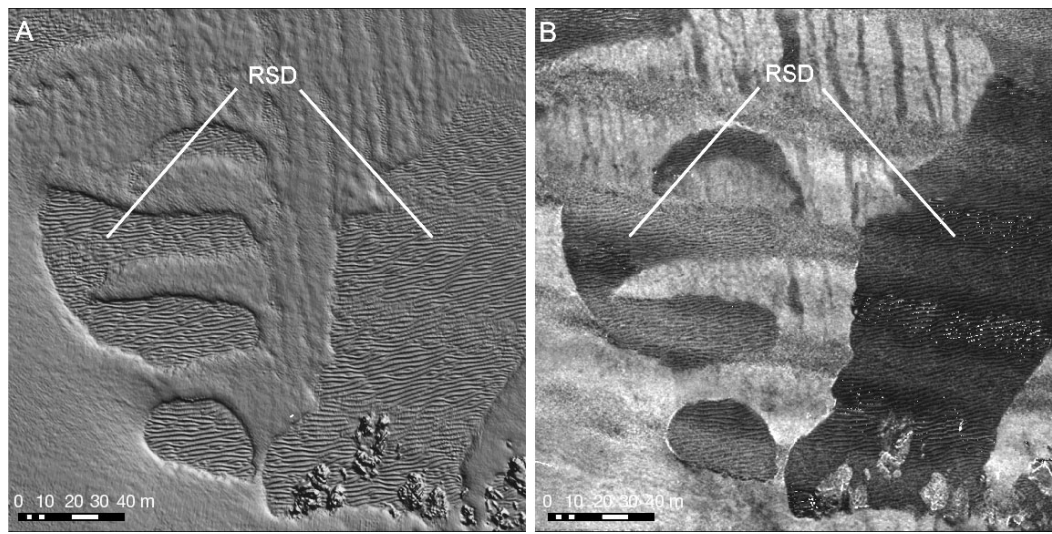

Fig. 1. Physical characteristics of rippled scour depressions (RSD) and adjacent fine sediment. (A) High-resolution multibeam and (B) side scan sonar images are presented from the same site in Monterey Bay, CA. Multibeam bathymetry in shaded relief shows distinct bedforms inside RSDs. Side scan image shows the higher reflectivity of coarser sediments (dark colors) inside RSDs ture within the low-relief unconsolidated sediments of California's coastal margin (A. Davis et al. unpubl.).

Hypothesized mechanisms for the formation of RSDs include tidal scour (Bellec et al. 2010), cross shore currents (Cacchione et al. 1984), storm generated downwelling (Garnaud et al. 2005), and alongshore currents (Murray \& Thieler 2004). Bottom currents have been measured as high as $60 \mathrm{~cm} \mathrm{~s}^{-1}$ inside RSDs (Bellec et al. 2010), compared to current speeds of $20 \mathrm{~cm} \mathrm{~s}^{-1}$ immediately adjacent to RSDs (Green et al. 2004). It is these strong currents that scour away fine sediment and create large bedforms. The bedforms then help to maintain the RSD by disrupting the laminar flow of water and creating a localized turbulence which resuspends fine sediment (Murray \& Thieler 2004).

While RSDs have been described from many parts of the world and are abundant on the inner continental shelf, the majority of research has focused on the physical character and geomorphic dynamics of these habitat features (Garnaud et al. 2005, Gutierrez et al. 2005, Lo Iacono \& Guillen 2008, Bellec et al. 2010). As a result, little is known about the biological communities associated with or the ecological importance of RSDs. Knowledge of RSD physical properties and the natural histories of many soft-bottom benthic species, however, can be used to make predictions about the likely influence of RSDs on the distribution, diversity, and abundance of those organisms. Many benthic species actively choose to associate with finer sediments, which can facilitate ease of burial for refuge (Tanda 1990, Burke et al. 1991, Gibson \& Robb 1992) and typically support higher abundances of infaunal prey items than coarser sediments (Abookire \& Norcross 1998, Brown \& Collier 2008). Moreover, those factors thought to be responsible for the maintenance of RSDs once formed (higher bottom currents, bedforminduced turbulent flow and subsequent resuspension and transport of fine sediments; Murray \& Thieler 2004) could negatively impact the density and diversity of benthic communities inside RSDs by limiting the settlement and recruitment of organisms (Jumars \& Nowell 1984, Kaiser \& Spencer 1996, Aller 1997) or interfering with the filter-feeding apparatus of some benthic invertebrates (Rhoads \& Young 1970, Pillay et al. 2007). 
The goal of the present study was to test the general hypothesis that the physical differences between RSDs and surrounding fine sediment habitats will result in predictable differences in the distribution and abundance of benthic species found inside and outside of RSDs. Specifically, we predicted density and richness of benthic organisms would be lower inside RSDs because coarse sediments generally support less diverse and less abundant communities (Abookire \& Norcross 1998, Snelgrove 1999, Brown \& Collier 2008). If present, these biotic differences between habitats should further increase with depth because the physical differences between habitats will also increase with depth along the disturbance gradient created by hydrodynamic scouring (Allen \& Moore 1996, Kostylev et al. 2001, Green et al. 2004). Additionally, we hypothesized that there will be larger fish inside RSDs because fish length has been correlated with bedform size and RSDs create and maintain larger bedforms than the surrounding fine sediment (Gerstner 1998, Auster et al. 2003a).

\section{MATERIALS AND METHODS}

The locations of 6 distinct RSD fields were identified in southern Monterey Bay (California, USA) from multibeam and side scan sonar data collected in 2001, 2004, and 2010 by the California State University, Monterey Bay, Seafloor Mapping Lab and compiled as part of the CSMP (Fig. 2). A survey cruise was conducted from 6 to 9 July 2010 aboard the RV 'Macginitie' to characterize the sediments and benthic communities associated with RSDs and adjacent areas along transects in these 6 study sites (Fig. 2).

\section{Collection and analysis of ROV video imagery}

Video transects were conducted using a small acoustically tracked remotely operated vehicle (ROV, LBV 200L, Seabotix) equipped with a digital color camera (560 line wide dynamic range, 0.3 lux), external LED lights, and paired $5 \mathrm{~cm}$ sizing lasers. The camera was mounted forward-facing at a $45^{\circ}$ angle. Each transect was conducted at a speed over ground of 0.5 to 1.0 knots at an altitude of 0.5 to $1.0 \mathrm{~m}$ above the seafloor and with the slightly buoyant tether kept off the bottom and trailing behind the advancing ROV. Survey planning and ROV navigation were conducted using Hypack Hydrographic Survey software, enabling both ROV and vessel position and tracks to be displayed in real time over multibeam bathymetry-derived habitat maps showing the location of previously mapped RSD features. Potential disturbance to fish was minimized by keeping the tether behind the ROV and off the seabed and by maintaining a constant slow vehicle speed and altitude. The position of the ROV was recorded relative to the ship's position every $0.5 \mathrm{~s}$ using an ultra-short baseline acoustic tracking system with ranges of $500 \mathrm{~m}$ horizontal and $150 \mathrm{~m}$ vertical, and range and bearing accuracies of $\pm 0.2 \mathrm{~m}$ and $\pm 3^{\circ}$ respectively (Micronav, Tritech). The ROV position fixes were converted to real world coordinates as they were logged by the Hypack software.

A total of $30 \mathrm{ROV}$ transects (10 to $55 \mathrm{~m}$ water depth) were conducted to collect continuous video imagery along paths spanning the transition from outside RSDs to inside RSDs (Fig. 2). Transects were stratified by depth, with start locations haphazardly selected in the study area based on wind and current direction at the time. Start positions were chosen to ensure that the vessel and ROV could maintain the desired speed and tether orientation along survey lines crossing comparable amounts of habitat inside and outside RSDs within each of 3 depth zones: shallow $(<15 \mathrm{~m})$, intermediate (15 to $30 \mathrm{~m})$, and deep $(>30 \mathrm{~m})$. Depth zone ranges were selected a priori based on known faunal depth distributions from previous work conducted the same study areas (Kvitek et al. 2008). Transect lengths ranged from 90 to $1260 \mathrm{~m}$ depending on vessel drift and the number of RSDs that could be covered along a single survey line (Fig. 2).

A total of $15 \mathrm{~h}$ of ROV survey video imagery was recorded, $14 \mathrm{~h}$ of which included usable imagery taken within the prescribed distance from the bottom and used in subsequent analyses. Data were extracted from the imagery using a frame-by-frame approach in which successive non-overlapping video frames were treated as individual quadrats. Frames were ignored where turbidity prevented reliable analysis or the ROV was not within $1 \mathrm{~m}$ of the seafloor.

All fish and benthic macro invertebrates that occurred within each sampling frame were counted and identified to the lowest taxonomic level possible. Organisms were then binned into one of 4 faunal groups: infaunal invertebrates, suspension feeders, invertebrate predators, and benthic predatory fishes (see Table 1). Because flatfish can generally be sorted into right-eyed and left-eyed families (Kramer et al. 1995) and this characteristic could be reliably distinguished from the video imagery for all individuals, here we assumed all right-eyed flatfish were 


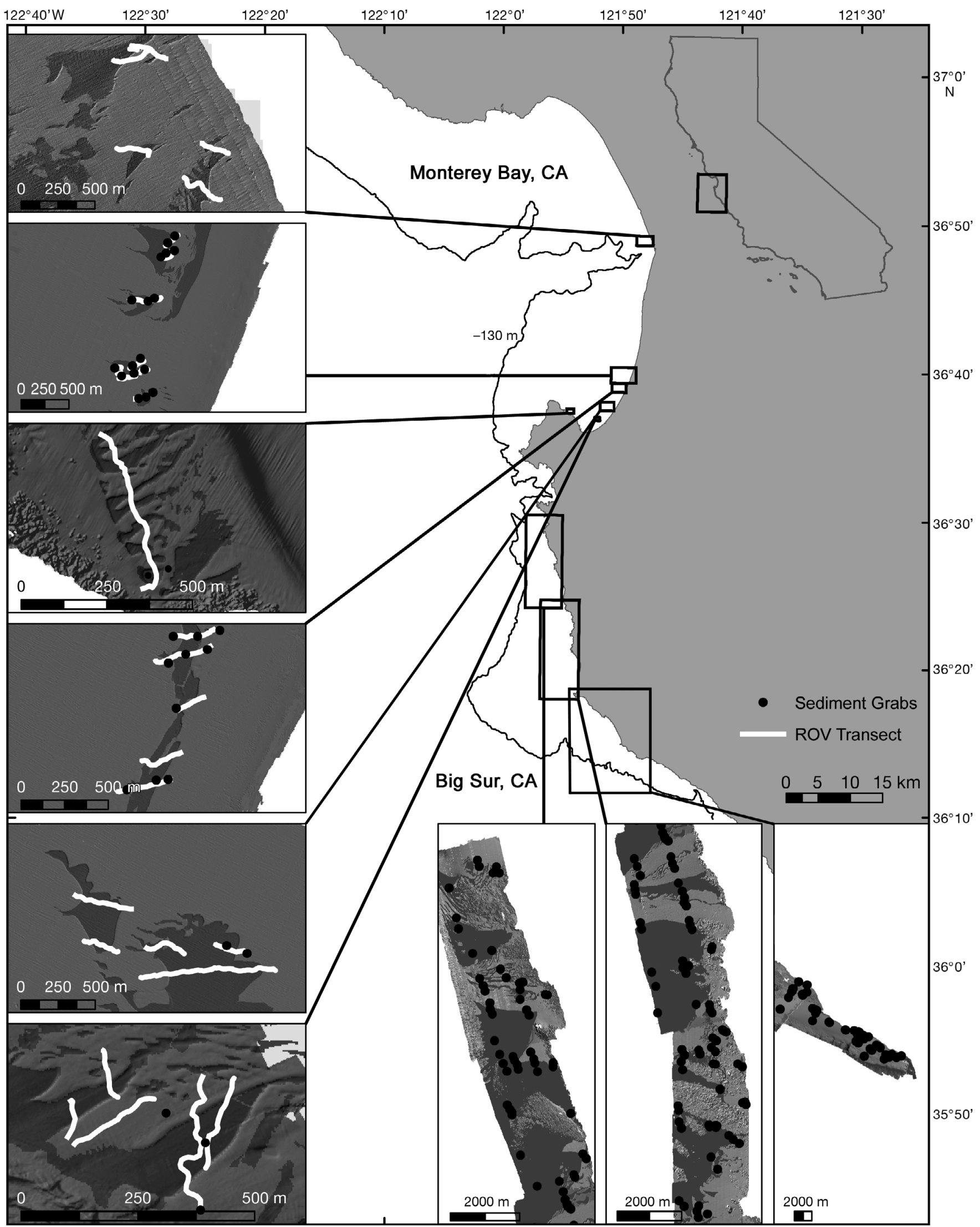

Fig. 2. Map of southern Monterey Bay study area and Big Sur shelf showing rippled scour depressions and the locations of ROV transects and sediment grab samples 
Pleuronectidae spp. and all left-eyed flatfish were Paralichthyidae spp. We do acknowledge that 2 species of Pleuronectidae known to occur in the study area can be either right or left-eyed (California Halibut and Starry Flounder), but given the ease with which these 2 particular species can be visually distinguished using other discernible morphological features, we concluded the right-eyed/left-eyed binning approach to be useful for the vast majority of the remaining flatfish observations.

The counts for suspension feeders, invertebrate predators, and fish groups were further pooled to provide a coarse measure of total faunal abundance and richness. A fourth group analyzed post hoc was composed of young-of-the-year (YOY) Sebastes spp. and analyzed separately. Parallel laser beams separated by $5 \mathrm{~cm}$ were used to measure total length (TL) of each fish observed, and the width of the sampling frame was used to facilitate calculation of total area covered by each transect. Fish smaller than $2 \mathrm{~cm}$ or that occurred only partially within the sampling frame were not counted. We strove to minimize any possibility of 'herding' fish into RSDs by maintaining constant ROV speed and altitude, with the tether always oriented aft and off the bottom, as recommended by Stoner et al. (2008). We observed no consistency in the direction taken by fish that swam out of the frame of view. Moreover, the YOY rockfish aggregations observed in the RSD fields did not move toward or away from the ROV. Rather, they first came into view as stationary groups on the far edge of the field of view and remained hovering in place within a meter of the bottom as the ROV passed through, with individuals only moving to the side as needed to get out of the direct path of the vehicle.

Percent cover was used to quantify the abundance of 3 infaunal invertebrate groups that were either too numerous to count as individuals within video frames (Dendraster excentricus) or for which indirect measures were required to estimate abundance (burrows for Urechis caupo and Callianassidae and arms protruding from the sediment for Ophiuroids). Because $U$. caupo and Callianassidae co-occur on the Monterey Bay shelf (Kvitek et al. 2008) and create similar burrow openings that can be difficult to distinguish from each other in video imagery, these 2 taxa were necessarily treated as a single infaunal group. For these 3 groups, percent cover was measured using a 100 point contact grid for sampling each video frame. This grid was superimposed over each sampling frame, and any point that contacted an organism or burrow opening was tallied. The sum of the tallied points for each faunal group was divided by the total number of points (100) to create a percent cover for each sampling frame.

Physical environment parameters including substrate, relief, bedform type, and water depth were recorded for each sampling frame. Habitat type (inside or outside) was determined using combinations of the physical parameters. Criteria used to define inside RSD habitat included coarse sediment substrate, bedform period $>0.5 \mathrm{~m}$, and amplitude $>$ $0.25 \mathrm{~m}$. Outside RSD habitat was defined as unconsolidated fine sediment substrate, bedform period < $0.5 \mathrm{~m}$, and amplitude $<0.25 \mathrm{~m}$. Bedform period and amplitude were estimated using the paired $5 \mathrm{~cm}$ lasers visible in each frame. The bedform period was confirmed using the data from the ROV's onboard forward-looking sector scanning sonar. Data QA/QC was conducted by randomly selecting and reanalyzing $1.5 \mathrm{~h}$ of video imagery.

Variogram analysis of abundance data was used to identify the optimal spatial scale for subsampling transects following the methods of Camarero et al. (2005). Semivariograms plotted the semivariance of total organism abundance in each transect versus distance $(\mathrm{m})$ between observations. Multidirectional $\left(0^{\circ}, 34^{\circ}, 90^{\circ}\right.$, and $\left.135^{\circ}\right)$ semivariograms of ROV transects were calculated and compared to a Gaussian model semivariogram with range $=60$, psill $=1$, and nugget $=1$ using a Cressie estimator. Distances where the experimental semivariance exceeded the modeled semivariogram indicated the distance below which spatial autocorrelation was likely present.

While transects crossed multiple habitats (Fig. 2), transects were subsampled post hoc into $10 \mathrm{~m}$ sampling units based on the optimal spatial scale indicated by the variogram analysis, with each sampling unit restricted to 1 habitat type (i.e. inside or outside RSD). To create the $10 \mathrm{~m}$ sampling units, each transect was apportioned into consecutive $10 \mathrm{~m}$ sampling units starting from the RSD transition zone and moving outward to ensure only 1 habitat type within each sampling unit. Any length of transect that could not be apportioned evenly into a $10 \mathrm{~m}$ sampling unit was discarded. Organism counts and percent cover measures collected from individual sampling frames were aggregated into this larger $10 \mathrm{~m}$ sampling unit for analysis.

Mean density and richness was calculated for individual taxa and groups (with the exception of the infaunal invertebrate group, which was quantified by percent cover) by summing the total number of organisms identified in each sampling frame of each $10 \mathrm{~m}$ long sampling unit and dividing by the average area of the sampling unit. The average area of the 
sampling unit was measured by the linear distance traveled by the ROV $(10 \mathrm{~m})$ multiplied by $0.87 \pm$ $0.02 \mathrm{~m}$, the average width of the sampling frame. To represent density and richness values per $10 \mathrm{~m}^{2}$, density and richness values were then multiplied by 1.15.

Welch's 2 sample $t$-test was used to test for significant differences in the mean faunal density and richness between habitat types for all enumerated groups. Two-way ANOVAs were used to test for significant differences in the mean density, richness, and percent cover values of individual groups between habitat and water depth. Data were tested for normality and equal variance to meet the assumptions of ANOVA. Density data were right skewed (i.e. Poisson distribution), and a square root transformation was performed prior to statistical analysis.

\section{Collection and analysis of sediment grain size}

Sediment grabs taken inside and outside of RSDs were conducted opportunistically along transects using a sediment sampler modeled after a Kahlsico Scoopfish to sample the upper $10 \mathrm{~cm}$ of sediment. Samples were only taken in locations where both multibeam imagery and video footage verified habitat type, and only whole samples were retained and analyzed. Coarse fraction analysis was conducted following the methods of Poppe et al. (2000) to calculate a mean grain size for each sample.

To assess how representative the physical characteristics of the Monterey Bay RSDs were of those found on the central California continental shelf, we analyzed an additional 190 archived sediment samples collected in 2006 from inside and outside of RSDs along $45 \mathrm{~km}$ of open coast immediately south of Monterey Bay using the same methods described above. A 1-way ANOVA with Tukey's HSD multiple comparison was performed to detect differences in the mean grain size between the 2 habitat types for both areas.

\section{RESULTS}

The ROV video surveys yielded 463 sampling units inside and 609 sampling units outside (each unit $10 \mathrm{~m}^{2}$ ) a total of 20 individual RSDs in Monterey Bay. A total of 2953 observations of 28 differ- ent fish and invertebrate taxa were derived from this video imagery. Individuals were identified belonging to $13(\mathrm{~N}=59), 25(2034)$, and 18 (860) separate taxa in the shallow, intermediate and deep depth zones, respectively. A total of 33 sediment grab samples from inside $(n=13)$ and outside $(n=20)$ the Monterey Bay RSDs across a 14 to $40 \mathrm{~m}$ depth range were collected and analyzed for mean grain size along with the 190 Big Sur shelf archive sediment samples collected in 2006 from inside $(n=103)$ and outside RSDs ( $\mathrm{n}=87$ ) spanning a depth range of 12 to $95 \mathrm{~m}$.

\section{Sediment grain size inside and outside RSDs}

Grain size analysis revealed all sediments collected inside of RSDs to be coarser than all sediments from outside RSDs across all depth zones for Monterey Bay and the Big Sur shelf (Fig. 3). In Monterey Bay, ANOVA and Tukey's multiple comparison test revealed mean $( \pm \mathrm{SE})$ grain size of sediments outside RSDs $(0.19 \pm 0.01 \mathrm{~mm})$ to be significantly finer than samples collected inside RSDs $(0.71 \pm 0.03 \mathrm{~mm}, \mathrm{p}<$ 0.001 ) but not significantly different from sediments outside RSDs on the Big Sur shelf to the south $(0.25 \pm$ $0.01 \mathrm{~mm}, \mathrm{p}=0.462$ ). The Big Sur shelf RSD mean grain size $(0.87 \pm 0.02 \mathrm{~mm})$ was significantly coarser than the outside sediments in Big Sur $(\mathrm{p}<0.001)$ and slightly but significantly coarser than the Monterey

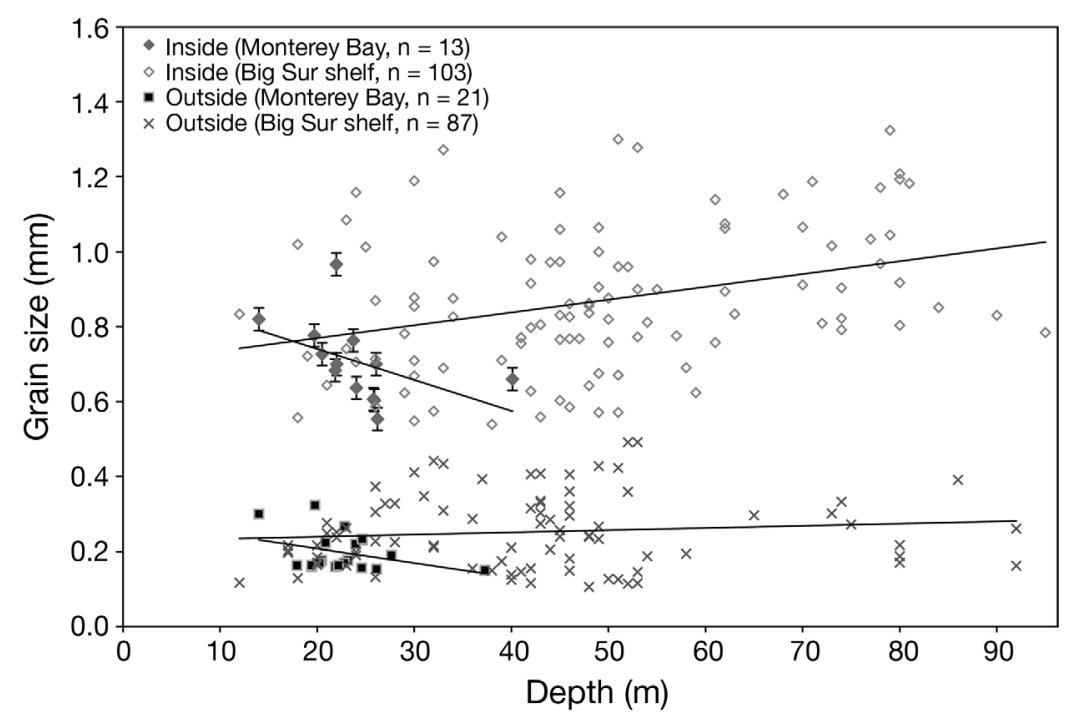

Fig. 3. Mean $( \pm \mathrm{SE})$ grain size of sediments collected at locations inside and outside of RSDs from 14 to $40 \mathrm{~m}$ water depth in Monterey Bay plotted with the means from 190 sediment samples collected inside and outside of RSDs across a 12 to $95 \mathrm{~m}$ depth range in 2006 along $45 \mathrm{~km}$ of the open Big Sur coast immediately south of Monterey Bay (see Fig. 2). There is no overlap in the grain sizes between samples taken inside and outside of RSDs. Linear trend lines llustrate relationships of grain size to water depth for each of the 4 data sets 
Bay RSDs $(p=0.001)$. While mean RSD grain sizes in Monterey Bay tended to decline with depth over the 14 to $40 \mathrm{~m}$ depth range sampled, the opposite trend was found on the Big Sur shelf when all samples from the much wider 12 to $95 \mathrm{~m}$ depth range were included (Fig. 3). However, no trend with depth was found in the Big Sur shelf grain size data over the same 14 to $40 \mathrm{~m}$ depth range as sampled in the Monterey Bay study area.

Visual observation of the sediment surface in the ROV video imagery further confirmed the relative differences in grain size inside and outside of all RSDs in all zones (Fig. 4). The coarse nature of the sediment and abundant small shell fragments were consistent features observed inside but not outside the RSDs.

\section{Effects of habitat on density and richness}

The overall mean $( \pm$ SE) faunal density for all taxa, excluding YOY Sebastes spp., enumerated as individuals across all depth zones outside RSDs $(2.63 \pm$ 0.14 ind. $10 \mathrm{~m}^{-2}$ ), was greater than those found inside RSDs $\left(1.71 \pm 0.09\right.$ ind $10 \mathrm{~m}^{-2}$; Welch's 2-sample $t$-test, $t=-4.82, \mathrm{df}=1068.06, \mathrm{p}<0.001)$. This same pattern was true for the 3 faunal groups of individually enumerated taxa. The density of suspension feeders across all depth zones was nearly 3 times as great outside RSDs $\left(0.23 \pm 0.04\right.$ ind. $\left.10 \mathrm{~m}^{-2}\right)$ as inside RSDs $\left(0.08 \pm 0.02\right.$ ind. $10 \mathrm{~m}^{-2}$; Welch's 2-sample $t$-test $t=-3.84, \mathrm{df}=926.78, \mathrm{p}<0.001)$. Similarly, the density of invertebrate predators was twice as great outside $\left(0.64 \pm 0.05\right.$ ind. $\left.10 \mathrm{~m}^{-2}\right)$ as inside RSDs $\left(0.30 \pm 0.03\right.$ ind. $10 \mathrm{~m}^{-2}$; Welch's 2 -sample $t$-test, $t=$ $-5.98, \mathrm{df}=1052.99, \mathrm{p}<0.001)$, and fish were more abundant outside $\left(1.76 \pm 0.11\right.$ ind. $\left.10 \mathrm{~m}^{-2}\right)$ than inside RSDs $\left(1.33 \pm 0.08\right.$ ind. $10 \mathrm{~m}^{-2}$; Welch's 2-sample $t$-test, $t=-2.28, \mathrm{df}=1069.99, \mathrm{p}=0.02)$. Significant differences in the abundances of 12 individual taxa were found between habitats in some depth zones, with 10 taxa having higher values outside RSDs and only Dendraster excentricus and YOY Sebastes spp. having higher numbers inside RSDs (Table 1).

Mean richness of individual groups was also generally greater outside RSDs than inside. The mean richness of combined faunal groups outside RSDs $\left(1.49 \pm 0.06\right.$ taxa $\left.10 \mathrm{~m}^{-2}\right)$ was greater than inside RSDs $\left(1.12 \pm 0.06\right.$ taxa $10 \mathrm{~m}^{-2}$; Welch's 2-sample $t$-test $, t=-4.54, \mathrm{df}=1068.72, \mathrm{p}<0.001)$. Mean richness of suspension feeders was greater outside RSDs $\left(0.14 \pm 0.02\right.$ taxa $\left.10 \mathrm{~m}^{-2}\right)$ than inside $(0.07 \pm 0.01$ taxa $10 \mathrm{~m}^{-2}$; Welch's 2-sample $t$-test, $t=-3.24, \mathrm{df}=1059.37$,
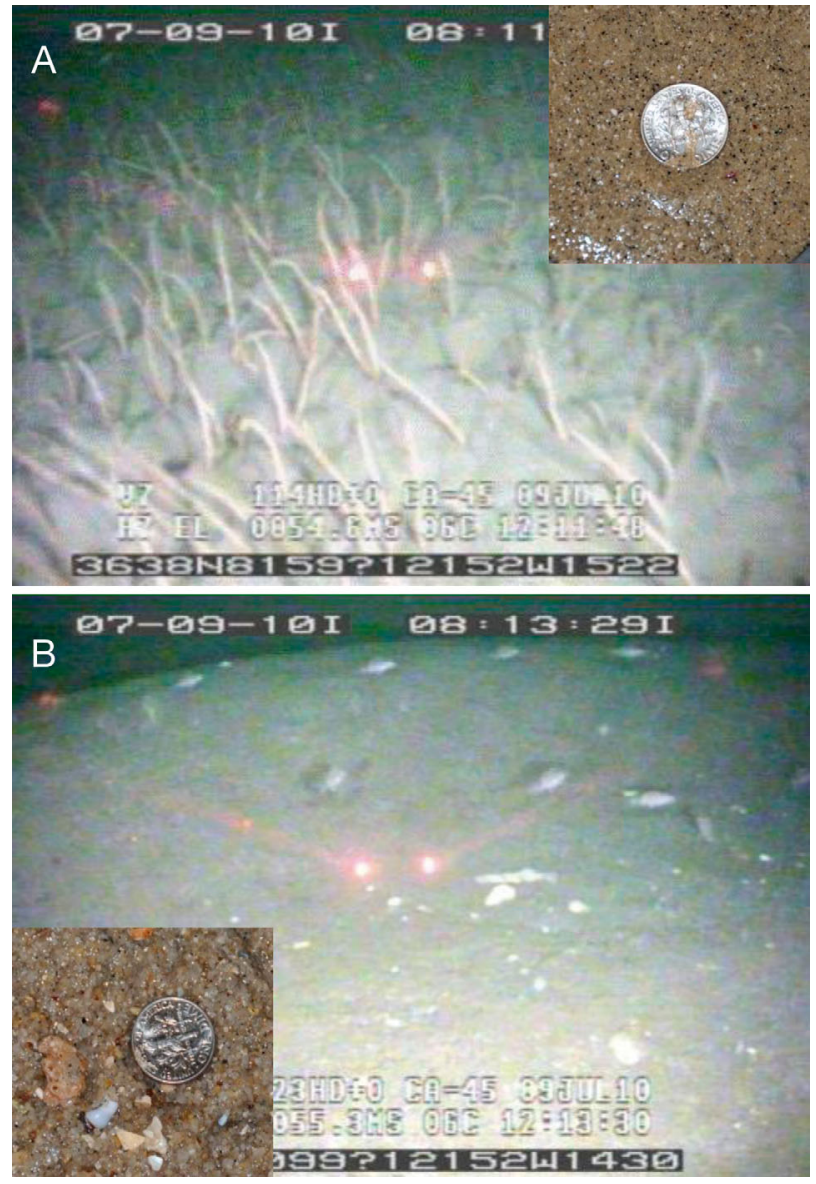

Fig. 4. ROV video frames taken in (A) $54.6 \mathrm{~m}$ water depth outside an RSD and (B) $55.3 \mathrm{~m}$ water depth inside an RSD at locations $17 \mathrm{~m}$ apart along a single deep zone transect. Insets are photographs of inside and outside RSD sediment grab samples from the deep zone with coin (USA dime) shown for scale. Abundant ophiuroid arms protrude from the finer sediment in (A) but are completely absent in (B), where YOY rockfish hover between the prominent and comparatively barren bedforms of the much coarser RSD sediment. Paired laser scaling dots seen in both frames are $5 \mathrm{~cm}$ apart

$\mathrm{p}=0.001)$, as was that of invertebrate predators $(0.48 \pm$ 0.03 and $0.25 \pm 0.02$ taxa $10 \mathrm{~m}^{-2}$ respectively; Welch's 2 -sample $t$-test, $t=-5.74, \mathrm{df}=1061.78, \mathrm{p}<0.001$ ). However, there was no significant difference in mean richness of fish outside RSDs $(0.86 \pm 0.04$ taxa $\left.10 \mathrm{~m}^{-2}\right)$ versus inside $\left(0.79 \pm 0.04\right.$ taxa $10 \mathrm{~m}^{-2}$; Welch's 2 -sample $t$-test, $t=-1.29, \mathrm{df}=1032.75, \mathrm{p}=0.20$ ).

\section{Effects of habitat and depth on density and richness}

Differences in density and richness of total fauna enumerated as individuals inside and outside of the 
Table 1. Two-way ANOVA summary of mean percent cover and density for individual taxonomic groups that comprise faunal groupings inside and outside of rippled scour depressions (RSD) by depth zone. Asterisks denote p-values $\left({ }^{*} 0.01,{ }^{* *} 0.001\right.$, ${ }^{* * *}<0.001$ ) of significant differences inside versus outside RSDs within a given depth zone for each taxonomic group. Values in bold indicate a significant interaction effect of habitat and depth for a given taxonomic group. Dashes indicate no individuals observed within that depth zone. Number of sampling units (n) are given for each habitat/depth category

\begin{tabular}{|c|c|c|c|c|c|c|}
\hline & \multicolumn{2}{|c|}{ Shallow } & \multicolumn{2}{|c|}{${ }_{-}$Intermediate -} & \multicolumn{2}{|c|}{ - Deep } \\
\hline & Inside & Outside & Inside & Outside & Inside & Outside \\
\hline \multicolumn{7}{|c|}{ Infaunal invertebrates $\left(\% \pm S E 10 \mathrm{~m}^{-2}\right)$} \\
\hline Dendraster excentrius & $2.0 \pm 0.60^{* * *}$ & $0.85 \pm 0.32$ & $0.00 \pm 0.00$ & - & - & - \\
\hline $\begin{array}{l}\text { Urechis caupo/ } \\
\text { Callianassidae }\end{array}$ & $1.29 \pm 0.46$ & $6.19 \pm 0.66^{* * *}$ & $1.0 \pm 0.22$ & $2.68 \pm 0.32^{* *}$ & $0.00 \pm 0.00$ & $0.10 \pm 0.07$ \\
\hline Ophiuroids & - & - & $0.00 \pm 0.00$ & $0.24 \pm 0.03$ & $0.03 \pm 0.00$ & $26.48 \pm 1.41^{* * *}$ \\
\hline \multicolumn{7}{|c|}{ Suspension feeders (mean $\pm S E$ ind. $10 \mathrm{~m}^{-2}$ ) } \\
\hline Metridium spp. & - & - & - & - & - & $0.18 \pm 0.14^{* * *}$ \\
\hline Ptilosarcus spp. & - & - & - & $0.11 \pm 0.02^{*}$ & $0.21 \pm 0.04$ & $0.72 \pm 0.14^{* * *}$ \\
\hline \multicolumn{7}{|c|}{ Invertebrate predators (mean $\pm S E$ ind. $10 \mathrm{~m}^{-2}$ ) } \\
\hline Asterina spp. & $0.03 \pm 0.03$ & $0.01 \pm 0.01$ & $0.05 \pm 0.01$ & $0.09 \pm 0.02$ & $0.11 \pm 0.03$ & $0.54 \pm 0.1^{* * *}$ \\
\hline Pisaster spp. & $0.09 \pm 0.05$ & $0.06 \pm 0.02$ & $0.00 \pm 0.00$ & $0.03 \pm 0.01$ & - & - \\
\hline Pychnopodia sp. & $0.06 \pm 0.06$ & - & $0.01 \pm 0.01$ & $0.01 \pm 0.01$ & $0.01 \pm 0.01$ & - \\
\hline Nassarius spp. & - & $0.06 \pm 0.03$ & $0.1 \pm 0.03$ & $0.17 \pm 0.03$ & - & $0.04 \pm 0.02$ \\
\hline Cancer spp. & - & $0.01 \pm 0.01$ & - & $0.06 \pm 0.01^{* * *}$ & $0.05 \pm 0.02$ & $0.07 \pm 0.03$ \\
\hline Pagurus spp. & - & - & - & - & $0.02 \pm 0.01$ & $0.13 \pm 0.05^{* * *}$ \\
\hline Octopus & - & - & $0.21 \pm 0.04$ & $0.23 \pm 0.03$ & - & - \\
\hline \multicolumn{7}{|c|}{ Fish $\left(\right.$ mean $\pm S E$ ind. $\left.10 \mathrm{~m}^{-2}\right)$} \\
\hline Ophiodon sp. & - & - & $0.06 \pm 0.02$ & $0.04 \pm 0.01$ & $0.02 \pm 0.01$ & $0.39 \pm 0.08^{* * *}$ \\
\hline Sebastes (YOY) spp. & - & - & $2.81 \pm 0.61^{* * *}$ & $0.20 \pm 0.04$ & $0.95 \pm 0.25$ & $0.72 \pm 0.13$ \\
\hline Paralichthyidae spp. & $0.09 \pm 0.05$ & $0.02 \pm 0.01$ & $0.63 \pm 0.07$ & $1.04 \pm 0.08^{* *}$ & $0.91 \pm 0.10$ & $1.22 \pm 0.24$ \\
\hline Pleuronectidae spp. & - & $0.02 \pm 0.02$ & $0.42 \pm 0.05$ & $1.05 \pm 0.08^{* *}$ & $0.81 \pm 0.09$ & $0.99 \pm 0.21$ \\
\hline Sampling units (n) & 39 & 145 & 250 & 376 & 174 & 88 \\
\hline
\end{tabular}

RSDs (excluding YOY Sebastes spp.) were not consistent across the 3 depth zones sampled. Density and richness of total fauna were greater outside RSDs in the intermediate and deep zones but not the shallow zone (Fig. 5). These differences by depth are reflected in the significant interaction found between habitat and water depth on both density (2-way ANOVA, $\mathrm{SS}=80.19, \mathrm{df}=5, F=49.14, \mathrm{p}<0.001)$ and richness (2-way ANOVA, SS $=298.91, \mathrm{df}=5, F=$ $50.63, \mathrm{p}<0.001$ ) of combined faunal groups.

Interaction between depth and habitat was significant for density and richness of suspension feeders and invertebrate predators ( $p<0.001$; Fig. 5). Density of suspension feeders was greater outside RSDs only in the deep zone $(p<0.001)$, but richness was greater outside in both the intermediate and deep zones $(\mathrm{p}=$ 0.01 and $p<0.001$, respectively). Density and richness of invertebrate predators were greater outside RSDs for the intermediate and deep zones $(\mathrm{p}<0.001)$. Density of fish was greater outside RSDs in the intermediate zone $(p<0.001)$, and richness of fishes was significantly greater outside RSDs in the intermediate zone.

Differences were also found in the abundance of those fauna for which percent cover was used as a measure (Dendraster excentricus, Urechis caupo/ Callianassidae burrows, and ophiuroids; Table 1, Fig. 4). Two-way ANOVA revealed significant interaction of depth and habitat for $D$. excentricus ( $\mathrm{SS}=$ 0.003, $\mathrm{df}=2, F=6.92, \mathrm{p}=0.001), U$. caupo/Callianassidae burrows ( $\mathrm{SS}=0.04, \mathrm{df}=2, F=9.22, \mathrm{p}=0.001$ ), and ophiuroids ( $\mathrm{SS}=2.30, \mathrm{df}=2, F=1059.71, \mathrm{p}<$ 0.001). D. excentricus was found almost exclusively within the shallow zone, where percent cover was significantly higher inside versus outside RSDs ( $p<$ 0.001). Mean percent cover of $U$. caupo/Callianassidae burrows was significantly greater outside RSDs in both the shallow and intermediate depth zones ( $p<0.001$ and $p=0.001$, respectively). Ophiuroids were absent from the shallow zone and rarely observed in the intermediate zone but were 3 orders of magnitude more abundant outside RSDs in the deep zone $(\mathrm{p}<0.001$; Table 1, Fig. 4).

\section{Fish size and density}

The mean size of flatfishes for both families combined was greater outside $(7.54 \pm 0.32 \mathrm{~cm})$ than inside $(5.72 \pm 0.20 \mathrm{~cm})$ RSDs. However, this pattern 

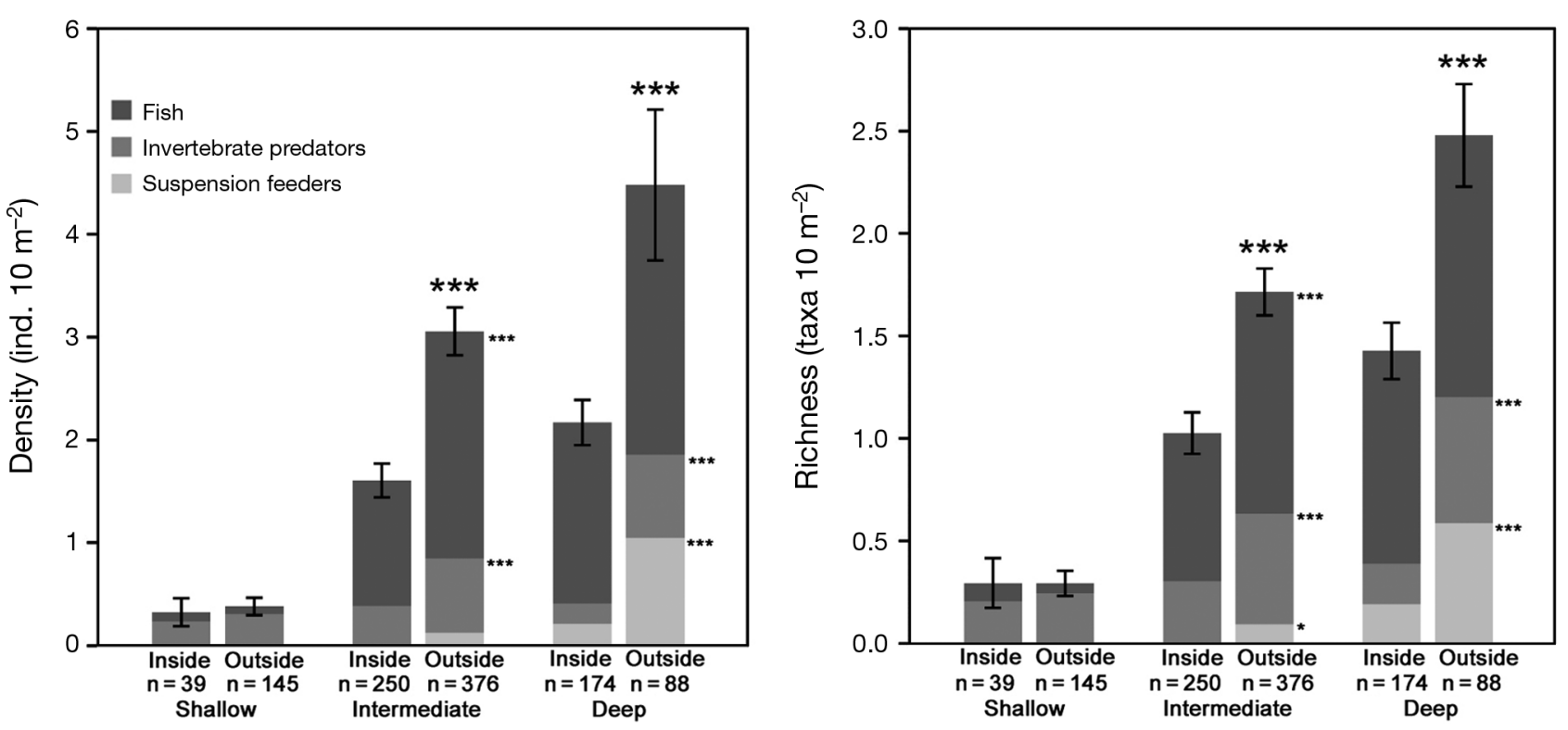

Fig. 5. Mean $( \pm$ SE) density and richness of the 3 faunal groupings inside and outside of RSDs for the 3 depth zones. Asterisks above the bars represent the p-values for differences in the combined mean for all 3 groups by habitat type. Asterisks to the right of the stacked bars denote $p$-values for significant differences found inside versus outside of RSDs for individual groups.

Number of sampling units (n) are given for each habitat/depth category. ${ }^{*} \mathrm{p}=0.01{ }^{* * *} \mathrm{p}<0.001$

varied significantly with depth (2-way ANOVA, SS = 862.85, $\mathrm{df}=5, F=21.33, \mathrm{p}<0.001$ ). Mean total length of combined flatfishes did not differ by habitat in the shallow or intermediate zones but was significantly greater outside RSDs in the deep zone $(\mathrm{p}<0.001$; Fig. 6). Because the observed Paralichthyidae spp. tended to be larger than Pleuronectidae spp., this difference had the potential of skewing the overall mean flatfish size difference between inside and outside RSDs if there had also been a habitat-specific difference in the abundance of these 2 taxa. However, a paired $t$-test revealed that there were no significant differences in the abundance of these 2 groups between habitats (Table 1). Flatfish was the only group of fish for which there was an adequate number of reliable measurements made inside and outside RSDs to perform size analyses on.

YOY Sebastes spp. abundance was significantly higher inside RSDs in the intermediate zone, while this group was never observed in the shallow zone for either habitat type (Figs. 4, $7 \&$ \&). Two-way ANOVA revealed a significant interaction between habitat and depth on mean density of YOY in the intermediate zone $(\mathrm{SS}=45.07, \mathrm{df}=5, F=27.40, \mathrm{p}<$ 0.001 ), where these fish were an order of magnitude more abundant inside than outside RSDs. While species identification was difficult for every YOY Sebastes spp. observation ( $\mathrm{N}=875)$, of the 605 YOY that could be identified to species, $45 \%$ were posi-

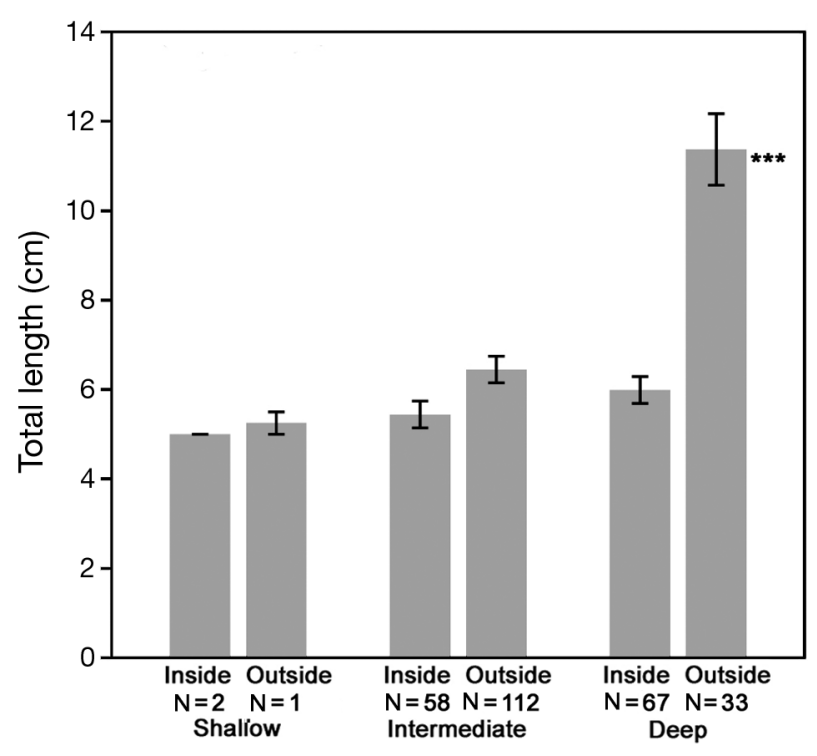

Fig. 6. Mean $( \pm \mathrm{SD})$ total length for combined flatfish groups inside and outside RSDs by depth zone. Asterisks denote p-values $\left({ }^{* *}<0.001,2\right.$-way ANOVA) of the relationship with habitat

tively identified as $S$. pinniger (canary rockfish) based on their distinctive dorsal spots. Other positively identified Sebastes species found in these RSD-associated YOY aggregations included $S$. miniatus (vermilion rockfish), $S$. saxicola (stripetail rockfish), S. mystinus (blue rockfish), and $S$. melanops 


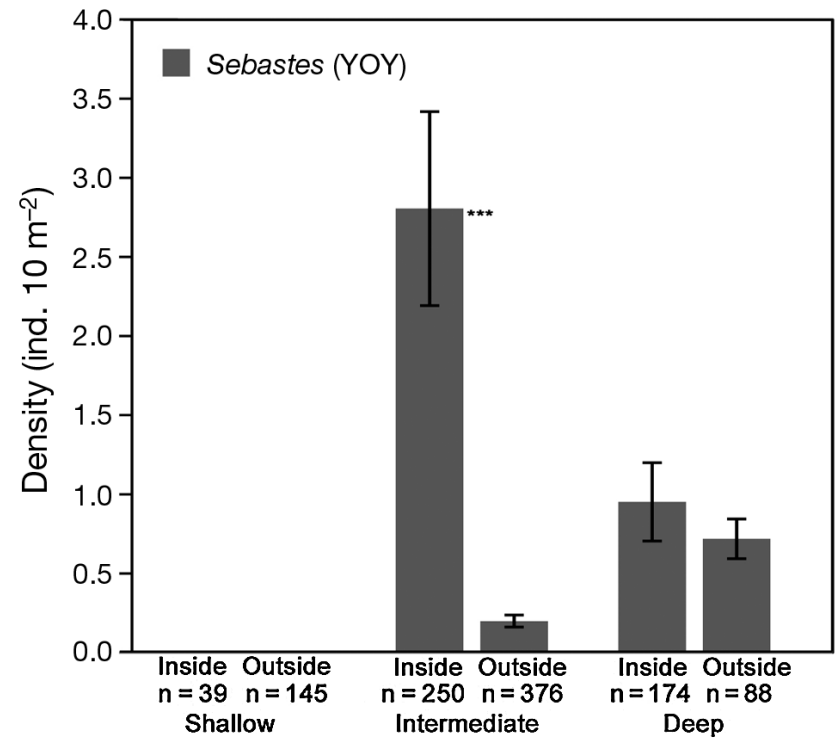

Fig. 7. Mean ( \pm SE) density of YOY Sebastes spp. inside and outside of rippled scour depressions by depth. Error bars represent the standard error, and sample sizes (n) are given.

$$
{ }^{* * *} \mathrm{p}<0.001
$$

(black rockfish). This preference for RSD habitat by YOY Sebastes spp. is further confirmed by the spatial distribution of all 875 YOY observations. YOY Sebastes spp. were observed in all but one of the intermediate and deep RSDs sampled and never in the shallow depth zone (Fig. 8a), with the overwhelming majority of observed YOY found inside intermediate and deep RSDs (90 and $72 \%$ respectively; Fig. 8b).

\section{DISCUSSION}

The present study determined that the biological communities associated with RSDs in southern Monterey Bay were significantly different from those found in the adjacent soft sediments. The RSDs sampled in the present study had sharply defined boundaries separating their coarser grain sediments and longer period bedforms from the 0.3 to $0.5 \mathrm{~m}$ higher adjacent and relatively featureless fine sediment plateau (Figs. 1 to 4 ). As predicted, these coarse sediments tended to support less dense and less diverse biological communities, and the density and richness of most faunal groups were lower inside RSDs for the intermediate and deep zones (Figs. 4 \& 5). Also as predicted, the relative difference between biological communities inside and outside RSDs increased with depth. However, the prediction that larger bedforms would support larger fish was not borne out. Indeed,
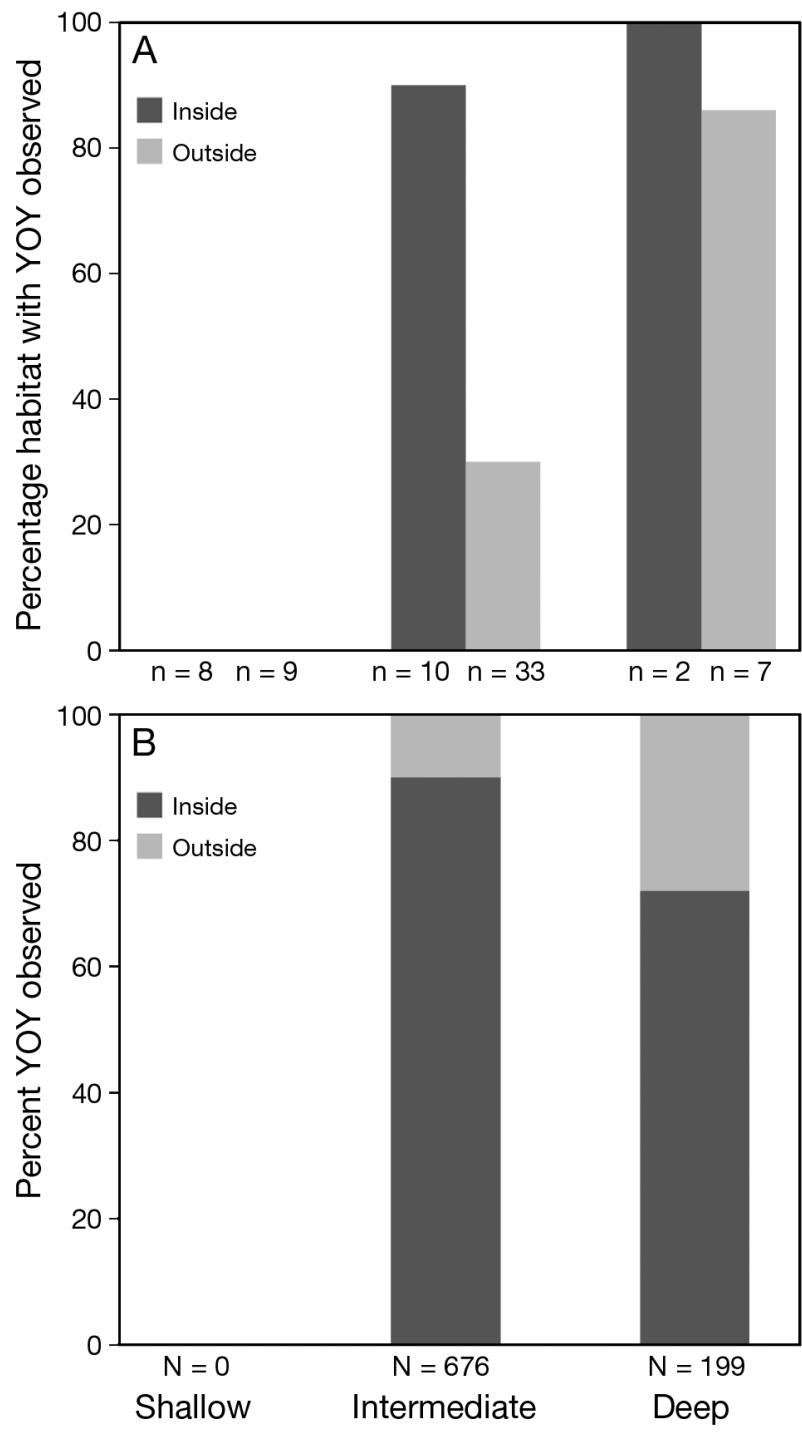

Fig. 8. YOY Sebastes spp. associated with RSD habitats by depth zone. (A) Percentage of individual RSD (inside) and non-RSD (outside) habitats sampled in which YOY Sebastes spp. were observed $(n=$ number of individual habitat features sampled). (B) Percentage of observed YOY individuals observed inside versus outside of RSD habitats within each depth zone ( $\mathrm{N}=$ total number of YOY identified as Sebastes spp. within each depth zone)

the opposite was true; smaller flatfish were found inside RSDs.

The finding that the densities of suspension feeders, invertebrate predators, and fishes, as well as the richness of suspension feeders and invertebrate predators, were significantly greater outside RSDs is consistent with our a priori predictions that RSDs are relatively depauperate habitats. This hypothesis was based on physical descriptions of RSDs as coarse sediment depressions found on fine sediment plateaus (Figs. 1 \& 3), combined with the well-established 
negative correlation between increasing grain size and species density and diversity (Snelgrove 1999, Brown \& Collier 2008). This negative relationship has been documented for many fishes and invertebrates known to actively settle on sediments of a specific grain size (Chia \& Crawford 1973, Kurihara 1999, Stoner \& Ottmar 2003), associating with finer sediments for ease of burying (Stoner \& Ottmar 2003), abundance of infaunal prey (Abookire \& Norcross 1998, Brown \& Collier 2008), or to maintain associations with other benthic organisms (Lindholm et al. 2004). While the present work highlights the physical and biological differences inside and outside of RSDs, future work should investigate the possibility of a halo- or ecotone effect at the typically welldefined RSD boundary where physical conditions change abruptly on the sub-meter scale.

As predicted, the effect of grain size alone did not determine the density or diversity of benthic communities (Snelgrove \& Butman 1994), which also varied significantly with water depth. The relative difference in density and richness of benthic communities inside and outside of RSDs increased with depth, and significant differences were observed in the intermediate and deep zones that were not observed in the shallow zone (Figs. 4 \& 5). Again, this prediction was based on the physical descriptions of both RSDs and the shallow nearshore zone as chronically disturbed by hydrodynamic currents and turbulence (Sternberg 1984, Green et al. 2004, Murray \& Thieler 2004).

On the continental shelf, grain size typically decreases with depth as the frequency and magnitude of wave/current disturbance rapidly decreases (Lenihan \& Micheli 2001, Allen 2006). However, the presence of RSDs extending beyond the $90 \mathrm{~m}$ isobaths on the central California continental shelf (Fig. 3) and to $160 \mathrm{~m}$ elsewhere (Bellec et al. 2010) indicate that disturbance inside RSDs is maintained over a broader depth range, thus amplifying the physical differences between habitats as depth increases (Green et al. 2004, Goff et al. 2005). This disturbance has a strong effect on the physical and biological characteristics of RSDs. In particular, hydrodynamic resuspension of sediments may have a negative impact on filter-feeding invertebrate species, whose feeding apparatus may be clogged with suspended sediments (Rhoads \& Young 1970, Pillay et al. 2007). Indeed, in the present study, suspension feeders were generally less dense and less rich inside RSDs (Table 1).

Additionally, hydrodynamic scouring may inhibit the settlement of infaunal organisms (Jumars \& Nowell 1984), which serve as food for many fish and invertebrate species (Quammen 1984, Edgar \& Shaw 1995). Moreover, while the focus of the present study was largely constrained to epifaunal taxa that could be identified in video imagery, the very strong and well-documented influence of grain size on the diversity and abundance of infaunal species (Hall \& Harding 1997, Abookire \& Norcross 1998, Brown \& Collier 2008) suggests that RSDs will likely have an even greater influence on those invertebrate communities.

Exploration of these differences offers a way to examine hypotheses of food availability as a mechanism for the differences in epifauna and benthic predatory fish described herein. The ROV video imagery revealed turbulent flow generated by even weak currents moving over the RSD bedforms during non-storm periods, sufficient to lift and suspend small particles from the seabed in visibly greater amounts than seen in the water column over nonRSD sediments and thereby potentially increasing prey availability to small fish inside RSDs compared to the otherwise richer surrounding non-RSD sediments.

There were also differences with respect to dominant taxonomic groups found between habitats and depth zones. This was especially true for Dendraster excentricus, Urechis caupo/Callianassidae burrows, and ophiuroids, which had significant differences in percent cover for the depth zone in which they were most abundant (Table 1, Fig. 4). Burrows (likely formed by U. caupo/Callianassidae) dominated outside RSDs in both the shallow and intermediate zones, while ophiuroids dominated outside RSD in the deep zone. The dominance of these organisms outside RSDs is especially relevant to the density and diversity of benthic communities, as both U. caupo/ Callianassidae and ophiuroids have been shown to create habitat for other fish and invertebrate species (MacGinitie 1934, Piepenburg \& Juterzenka 1994).

While the strong interaction between habitat and depth on the density of organisms and diversity of benthic communities has been well established (Warwick \& Davies 1977, Barry \& Dayton 1991, Snelgrove \& Butman 1994, Whitman et al. 2004), no previous work had examined the distribution and abundance of benthic communities associated with RSDs. The present study offers a first look at the ecological influence of these abundant features, and our results show RSDs conform to the general understanding of how benthic communities respond to fine scale physical differences in soft sediment habitats (i.e. grain size, bedforms, and hydrodynamic disturbance). However, many questions remain as to the larger scale significance of RSDs, including how RSD size, 
configuration, and latitudinal distribution mediate the biological relationships observed in the present study and ultimately the significance of RSDs with respect to marine spatial planning (i.e. ecosystembased management and marine protected area [MPA] design; Browman \& Stergiou 2004, Pikitch et al. 2004, Gleason et al. 2010).

Most surprising, and of potentially great significance for marine spatial planning, was the use of RSDs by fishes. While differences in fine scale physical variables allowed us to make reliable predictions about the overall distribution of benthic communities with respect to RSDs, we did not anticipate finding small flatfish and abundant YOY Sebastes spp. inside RSDs (Figs. 4, $6 \& 7$ ). The present study revealed flatfish to be significantly smaller inside RSDs (Fig. 6). We had predicted, based on the larger size of bedforms inside RSDs, to find larger fish. This unexpected finding is likely due to a combination of physical and biological interactions. The larger bedforms inside RSDs can act as a refuge for fish small enough to tuck into their lee (Gerstner 1998). As the size of the organism increases, its ability to benefit from refuge between bedforms may diminish. Furthermore, the main predators of juvenile flatfish are larger fishes (Gibson \& Robb 1996), which were more abundant outside RSDs. While the mechanism and seasonality of this relationship needs to be investigated further, these physical and biological factors may create an incentive for small fish to seek out RSDs despite potentially harsher physical conditions. This finding suggests a potential ecological role of RSDs as previously undescribed nursery habitat, which has important implications for the design of MPA networks (Beck et al. 2001, Gillanders et al. 2003).

The significantly greater density of YOY Sebastes spp. inside RSDs within the intermediate depth zone and their strong preference for RSDs in both the intermediate and deep zones were surprising discoveries (Figs. $7 \& 8$ ). While many species of rockfish are known to recruit in late summer to early fall (Carr 1991, Love et al. 1991, Johnson et al. 2001, Caselle et al. 2010) to a variety of habitats including kelp canopy (Carr 1991, Nelson 2001, Johnson 2006), high-relief hard substrate (Carlson \& Straty 1981, Carr 1991, Johnson 2007), deep low-relief rock reefs (Anderson \& Yoklavich 2007, Love et al. 2009), and shallow surfgrass beds (Guido et al. 2004), the importance of soft substrata for the young of deep-dwelling rockfish species is relatively unknown (Love et al. 1991, Johnson et al. 2001). The intermediate depth zone RSDs investigated here supported densities of YOY Sebastes spp. comparable to densities found in artificial reefs $\left(0.13\right.$ to 0.6 fish $10 \mathrm{~m}^{-2}$; West et al. 1994) and kelp canopies (10 to 40 fish $10 \mathrm{~m}^{-3}$; Carr 1991). This comparison was particularly true for the most abundant YOY we observed, $S$. pinniger. Indeed, RSDs may offer ideal conditions as nursery habitats for these fish, with the larger bedforms generating turbulent flow that provides a rich source of suspended organic material and small prey lifted off the bottom, as well as offering refuge from predators or currents.

The potential importance of RSDs as nursery habitat is underscored by the fact that $45 \%$ of the identified YOY were canary rockfish Sebastes pinniger, some populations of which are currently classified as overfished (Wallace \& Cope 2011). Given the large areal extent of RSD habitat now documented for the California continental shelf $\left(385 \mathrm{~km}^{2}\right.$ compared to $616 \mathrm{~km}^{2}$ of rocky habitat) and the fact that the majority of these features occur immediately offshore of rocky reefs (A. Davis et al. unpubl.), RSDs may have important implications for the replenishment of adult rockfish on those adjacent reefs and therefore the performance of MPAs in terms of faster than expected population recovery rates. Additionally, the widespread and abundant distribution of RSDs along the California coast may serve as conduits for gene flow between widely spaced reefs, thereby increasing the connectivity of rockfish populations on the west coast of the United States (Miller \& Shanks 2004, Hyde \& Vetter 2009). If true, this mechanism has significant implications for marine spatial planning efforts, such as California's Marine Life Protection Act, which mandates that the state's MPA system be designed to function as a network facilitating connectivity of populations through larval dispersal and ontogenetic migrations (CDFG 2008). The timing of the present study (July) was fortuitous for observing YOY rockfish, but further sampling of these habitats seasonally will be required to determine the term of residency for the young of these and other species throughout the year.

Recently collected high-resolution seafloor maps of the California continental shelf reveal RSDs to be abundant and responsible for making soft bottom habitats much more heterogeneous than previously thought (Morrisey et al. 1992, Kostylev et al. 2001, Brown \& Collier 2008, A. Davis et al. unpubl.). Now, with the results presented here, it is also clear that RSD-generated heterogeneity adds a significant level of ecologically important patchiness to the continental shelf, challenging the common assumption within many marine resource management strategies that soft sediments can be treated as homogenous habitats. 
Acknowledgements. We thank the Marine Technology Society, International Women's Fishing Association, Friends of Moss Landing Marine Labs, and the California State University Monterey Bay (CSUMB) Undergraduate Research Opportunities Center for financial support. We also thank A. Davis, C. Mueller, and J. Carrillo for help with the ROV surveys, J. Vasques, M. Carr, and M. Young for aid in manuscript preparation, T. Laidig for fish identifications, D. Smith for sediment analysis, and C. Garza for statistical advice. This research would not have been possible without the high-resolution seafloor data and maps generated by the California Ocean Protection Council's California Seafloor Mapping Project and CSUMB Seafloor Mapping Lab.

\section{LITERATURE CITED}

Abookire AA, Norcross BL (1998) Depth and substrate as determinants of distribution of juvenile flathead sole (Hippoglossoides elassodon) and rock sole (Pleuronectes bilineatus), Kachemak Bay, Alaska. J Sea Res 39: 113-123

Allen MJ (2006) Continental shelf and upper slope. In: Allen L, Pondella DJ, Horn M (eds) The ecology of marine fishes: California and adjacent waters. University of California Press, Berkeley, CA, p 167-202

Allen MJ, Moore SL (1996) Spatial variability in Southern California demersal fish and invertebrate catch parameters in 1994. In: Allen MJ, Francisco C, Hallock D (eds) Annual report 1994-1995. Southern California Coastal Water Research Project, Westminster, CA, p 114-127

Aller JY (1997) Benthic community responses to temporal and spatial gradients in physical disturbance within a deep-sea western boundary region. Deep-Sea Res I 44: 39-69

Anderson TJ, Yoklavich MM (2007) Multiscale habitat associations of deepwater demersal fishes off central California. Fish Bull 105:168-179

Auster PJ, Malatesta RJ, LaRosa SC, Cooper RA, Stewart LL (1991) Microhabitat utilization by the megafaunal assemblage at a low relief outer continental shelf siteMiddle Atlantic Bight, USA. J Northwest Atl Fish Sci 11: 59-69

Auster PJ, Lindholm J, Schaub S, Funnell G, Kaufman LS, Valentine PC (2003a) Use of sandwave habitats by silver hake. J Fish Biol 62:143-152

Auster PJ, Lindholm J, Valentine PC (2003b) Variation in habitat use by juvenile Acadian redfish, Sebastes fasciatus. Environ Biol Fishes 68:381-389

Barry JP, Dayton PK (1991) Physical heterogeneity and the organization of marine communities. In: Kolasa J, Pickett STA (eds) Ecological heterogeneity. Springer Verlag, New York, NY, p 269-320

Beck MW, Heck KL, Able KW, Childers DL and others (2001) The role of nearshore ecosystems as fish and shellfish nurseries. Bioscience 51:633-641

Bellec VK, Boe R, Rise L, Slagstad D, Longva O, Dolan M (2010) Rippled scour depressions on the continental shelf bank slopes off Nordlan and Troms, Northern Norway. Cont Shelf Res 30:1056-1069

Browman HI, Stergiou KI (2004) Perspectives on ecosystembased approaches to the management of marine reserves. Mar Ecol Prog Ser 274:269-303

Brown CJ, Collier JS (2008) Mapping benthic habitat in regions of gradational substrata: an automated approach utilizing geophysical, geological, and biological relationships. Estuar Coast Shelf Sci 78:203-214

Burke JS, Miller JM, Hoss DE (1991) Immigration and settlement pattern of Paralichthys dentatus and P. lethostigma in an estuarine nursery ground, North Carolina, USA. Neth J Sea Res 37:393-405

Butman CA, Grassle JP, Webb CM (1988) Substrate choices made by marine larvae in still water in a flume flow. Nature 333:771-773

Cacchione DA, Drake DE, Grant WD, Tate GB (1984) Rippled scour depression on the inner continental shelf off central California. J Sediment Petrol 54:1280-1291

CDFG (California Department of Fish and Game) (2008) California Marine Life Protection Act: master plan for marine protected areas. www.dfg.ca.gov/mlpa/pdfs/ revisedmp0108.pdf

Camarero JJ, Gutiérrez E, Fortin MJ, Ribbens E (2005) Spatial patterns of tree recruitment in a relict population of Pinus uncinata: forest expansion through stratified diffusion. J Biogeogr 32:1979-1992

Carlson HR, Straty RR (1981) Habitat and nursery grounds of Pacific rockfish, Sebastes spp., in rocky coastal areas of southeastern Alaska. Mar Fish Rev 43:13-19

Carr MH (1991) Habitat selection and recruitment of an assemblage of temperate zone reef fishes. J Exp Mar Biol Ecol 146:113-137

Caselle JE, Carr MH, Malone D, Wilson JR, Wendt DE (2010) Can we predict interannual and regional variation in delivery of pelagic juveniles to nearshore populations of rockfishes (genus Sebastes) using simple proxies of ocean conditions? CCOFI Reports 51:91-105

Chia FS, Crawford BJ (1973) Some observations on gametogenesis, larval development, and substratum selection of the sea pen, Ptilosarcus gurneyi. Mar Biol 23:73-82

> Diaz RJ, Cutter GR, Able KW (2003) The importance of physical and biogenic structure to juvenile fishes on the shallow inner continental shelf. Estuar Coast 26:12-20

Diesing M, Kubicki A, Winter C, Schwarzer K (2006) Decadal scale stability of sorted bedforms, German Bight, southeastern North Sea. Cont Shelf Res 26: 902-916

> Edgar GJ, Shaw C (1995) The production and trophic ecology of shallow-water fish assemblages in southern Australia. II. Diets of fishes and trophic relationships between fishes and benthos at Western Port, Victoria. J Exp Mar Biol Ecol 194:83-106

Garnaud S, Lesueur P, Garlan T (2005) Origin of rippled scour depressions associated with cohesive sediments in a shoreface setting (eastern Bay of Seine, France). GeoMar Lett 25:34-42

Gerstner CL (1998) Use of substratum ripples for flow refuging by Atlantic cod, Gadus morhua. Environ Biol Fishes 51:455-460

Gibson RN, Robb L (1992) The relationship between body size, sediment grain size and the burying ability of juvenile plaice, Pleuronectes platessa L. J Fish Biol 40: 771-778

Gibson RN, Robb L (1996) Piscine predation on juvenile fishes on a Scottish sandy beach. J Fish Biol 49:120-138

> Gillanders BM, Able KW, Brown JA, Eggleston DB, Sheridan PF (2003) Evidence of connectivity between juvenile and adult habitats for mobile marine fauna: an important component of nurseries. Mar Ecol Prog Ser 247: 281-295 
Gleason M, Mcreary S, Miller-Henson M, Ugoretz J, Fox E, Merrifield M, McClintock W, Serpa P, Hoffman K (2010) Science-based and stakeholder-driven marine protected area network planning: a successful case study from north central California. Ocean Coast Manag 53:52-68

Goff JA, Mayer LA, Traykovski P, Buynevich I and others (2005) Detailed investigations of sorted bedforms, or 'rippled scour depressions,' with the Martha's Vineyard Coastal Observatory, Massachusetts. Cont Shelf Res 25: 461-484

Green MO, Vincent CE, Trembanis AC (2004) Suspension of coarse and fine sand on a wave-dominated shoreface, with implications for the development of rippled scour depressions. Cont Shelf Res 24:317-335

> Guido P, Omori M, Katayama S, Kimura K (2004) Classification of juvenile rockfish, Sebastes inermis, to Zostera and Sargassum beds, using the macrostructure and chemistry of otoliths. Mar Biol 145:1243-1255

Gutierrez BT, Voulgais G, Thieler ER (2005) Exploring the persistence of sorted bedforms on the inner continental shelf of Wrightsville Beach, North Carolina. Cont Shelf Res 25:65-90

> Hall SJ, Harding MJ (1997) Physical disturbance and marine benthic communities: the effects of mechanical harvesting of cockles on non-target benthic infauna. J Appl Ecol 34:497-517

> Hyde JR, Vetter RD (2009) Population genetic structure in the redefined vermilion rockfish (Sebastes miniatus) indicates limited larval dispersal and reveals natural management units. Can J Fish Aquat Sci 66:1569-1581

Johnson DW (2006) Density dependence in marine fish populations revealed at small and large spatial scales. Ecology 87:319-325

Johnson DW (2007) Habitat complexity modifies post-settlement mortality and recruitment dynamics of a marine fish. Ecology 88:1716-1725

Johnson KA, Yoklavich MM, Caillet GM (2001) Recruitment of three species of juvenile rockfish (Sebastes spp.) on soft benthic habitat in Monterey Bay, California. CCOFI Rep 42:153-166

Jumars PA, Nowell AR (1984) Fluid and sediment dynamic effects on marine benthic structure. Am Zool 24:45-55

Kaiser MJ, Spencer BE (1996) The effects of beam-trawl disturbance on infaunal communities in different habitats. J Anim Ecol 65:348-358

> Kostylev VE, Todd BJ, Fadar GB, Courtney RC, Cameron GD, Pickerill RA (2001) Benthic habitat mapping on the Scotian shelf based on multibeam bathymetry, surficial geology, and sea floor photographs. Mar Ecol Prog Ser 219:121-137

Kramer DE, Barss WH, Paust BC, Bracken BE (eds) (1995) Guide to Northeast Pacific flatfishes. Alaska Sea Grant College Program, Anchorage, AK

Kurihara T (1999) Effects of sediment type and food abundance on the vertical distribution of the starfish Asterina pectinfera. Mar Ecol Prog Ser 181:269-277

Kvitek RG, Goldberg JD, Smith GJ, Doucette GJ (2008) Domoic acid contamination within eight representative species from the benthic food web of Monterey Bay, California, USA. Mar Ecol Prog Ser 367:35-47

Langton RW, Watling L (1990) The fish-benthos connection: a definition of prey groups in the Gulf of Maine. In: Barnes M, Gibson RN (eds) Trophic relationships in the marine environment. Aberdeen University Press, Aberdeen, p 424-438
Lenihan HS, Micheli F (2001) Soft sediment communities. In: Bertness MD, Gaines SD, Hay ME (eds) Marine community ecology. Sinauer Associates, Sunderland, MA, p 253-287

> Lindholm J, Auster P, Valentine P (2004) Role of a large marine protected area for conserving landscape attributes of sand habitats on Georges Bank (NW Atlantic). Mar Ecol Prog Ser 269:61-68

> Lindholm J, Auster PJ, Knight A (2007) Site fidelity and movement of adult Atlantic cod Gadus morhua at deep boulder reefs in the western Gulf of Maine, USA. Mar Ecol Prog Ser 342:239-247

> Lo Iacono C, Guillen J (2008) Environmental conditions for gravelly and pebbly dunes and sorted bedforms on a moderate-energy inner shelf (Marettimo Island, western Mediterranean). Cont Shelf Res 28:245-256

> Love MS, Carr MH, Haldorson LJ (1991) The ecology of substrate-associated juveniles of the genus Sebastes. Environ Biol Fishes 30:225-243

Love MS, Yoklavich M, Schroeder DM (2009) Demersal fish assemblages in the Southern California bight based on visual surveys in deep water. Environ Biol Fishes 84: 55-68

MacGinitie GE (1934) The natural history of Calianassa californiensis Dana. Am Midl Nat 15:166-177

Miller JA, Shanks AL (2004) Evidence for limited larval dispersal in black rockfish (Sebastes melanops): implications for population structure and marine-reserve design. Can J Fish Aquat Sci 61:1723-1735

> Morrisey DJ, Howitt L, Underwood AJ, Stark JS (1992) Spatial variation in soft bottom benthos. Mar Ecol Prog Ser 81:197-204

> Murray AB, Thieler ER (2004) A new hypothesis and exploratory model for the formation of large-scale innershelf sediment sorting and 'rippled scour depressions'. Cont Shelf Res 24:295-315

Nelson PA (2001) Behavioral ecology of young-of-the-year kelp rockfish, Sebastes atrovirens Jordan and Gilbert (Pisces: Scorpaenidae). J Exp Mar Biol Ecol 256:33-50

> Piepenburg D, Juterzenka K (1994) Abundance, biomass, and spatial distribution pattern of brittle stars (Echinodermata: Ophiuroidea) on the Kolbensey Ridge north of Iceland. Polar Biol 14:185-194

Pikitch EK, Santora C, Babcock EA, Bakun A and others (2004) Ecosystem-based fishery management. Science 305:346-347

Pillay D, Branch GM, Forbes AT (2007) The influence of bioturbation by the sandprawn Callianassa kraussi on the feeding and survival of bivalve Eumarcia paupercula and the gastropod Nassarius kraussianus. J Exp Mar Biol Ecol 344:1-9

Poppe LJ, Eliason AH, Fredericks JJ, Rendigs RR, Blackwood D, Polloni CF (2000) Grain size analysis of marine sediments: methodology and data processing. US Geol Surv Rep 00-358, Woods Hole, MA

> Quammen ML (1984) Predation by shorebirds, fish, and crabs on invertebrates in intertidal mudflats: an experimental test. Ecology 65:529-537

Rhoads DC, Young DK (1970) Influence of deposit-feeding organisms on sediment stability and community trophic structure. J Mar Res 28:150-178

Snelgrove PV (1999) Getting to the bottom of marine biodiversity: sedimentary habitats. Bioscience 49:129-137

Snelgrove PV, Butman CA (1994) Animal-sediment relationships revisited: cause versus effect. Oceanogr Mar 
Biol Annu Rev 32:111-177

Sternberg RW (1984) Sedimentation processes on continental shelves. In: Haq BU, Milliman JD (eds) Marine geology and oceanography of Arabian Sea and coastal Pakistan. Van Nostrand \& Reinhold, New York, NY, p 137-157

Stoner AW, Ottmar ML (2003) Relationships between the size-specific sediment preferences and burial capability in juveniles of two Alaskan flatfishes. J Exp Mar Biol Ecol 282:85-101

Stoner AW, Spencer ML, Ryer CH (2007) Flatfish-habitat associations in Alaskan nursery grounds: use of continuous video records for multiscale spatial analysis. J Sea Res 57:137-150

Stoner AW, Ryer CH, Parker SJ, Auster PJ, Wakefield WW (2008) Evaluating the role of fish behavior in surveys conducted with underwater vehicles. Can J Fish Aquat Sci 65:1230-1243

Tanda M (1990) Studies of burying ability in sand and selection to the grain size for hatchery-reared marbled sole and Japanese flounder. Bull Jpn Soc Sci Fish 56: 1543-1548

Editorial responsibility: Jana Davis, Annapolis, Maryland, USA
Wallace JR, Cope JM (2011) Status update of the US canary rockfish resource in 2011. www.pcouncil.org/wpcontent/uploads/Canary_2011_Assessment_Update.pdf

Warwick RM, Davies JR (1977) The distribution of sublittoral macrofauna communities in the Bristol Channel in relation to the substrate. Estuar Coast Mar Sci 5: 267-288

West JE, Buckley RM, Doty DC (1994) Ecology and habitat use of juvenile rockfishes (Sebastes spp.) associated with artificial reefs in Puget Sound, Washington. Bull Mar Sci 55:344-350

Whitman JD, Etter RJ, Smith F (2004) The relationship between regional and local species diversity in marine benthic communities: a global perspective. Proc Natl Acad Sci USA 101:15644-15669

Woodin SA (1978) Refuges, disturbance, and community structure: a marine soft-bottom example. Ecology 59: 274-284

Zajac RN, Whitlatch RB, Thrush SF (1998) Recolonization and succession in soft-sediment infaunal communities: the spatial scale of controlling factors. Hydrobiologia 375-376:227-240

Submitted: January 18, 2012; Accepted: July 18, 2012

Proofs received from author(s): November 2, 2012 